\title{
A Review and Prospects of Literature on Proactivity
}

\author{
Huishan Zhang \\ Jinan University, Guangzhou, China \\ Email: 1657391031@qq.com
}

How to cite this paper: Zhang, H. S. (2020). A Review and Prospects of Literature on Proactivity. Open Journal of Social Sciences, 8, 211-230.

https://doi.org/10.4236/jss.2020.82017

Received: January 14, 2020

Accepted: February 25, 2020

Published: February 28, 2020

Copyright $\odot 2020$ by author(s) and Scientific Research Publishing Inc. This work is licensed under the Creative Commons Attribution International License (CC BY 4.0).

http://creativecommons.org/licenses/by/4.0/

\begin{abstract}
Proactivity refers to the tendency of individuals to proactively promote the meaning of others and/or the environment, such as employees proactively proposing solutions, actively seeking job feedback, and actively innovating. Proactivity is very important for the development of employees and organizations. Since the domestic scholars Liu Mi and others and Hu Qing and others have reviewed the relevant research on employee's proactive personality and proactive behavior in 2007 and 2011 respectively, other domestic scholars have published relevant employees in well-known journals at home and abroad. Dozens of proactive research are based on different theoretical perspectives. This paper firstly reviews the development of proactivity's construction, measurement and research methods, then analyzes the formation and mechanism of proactivity based on two perspectives of personal characteristics and behavior process, and further proposes the direction and prospect of future research.
\end{abstract}

\section{Keywords}

Proactivity, Proactive Personality, Proactive Behavior, Approach-Avoidance Framework

\section{Introduction}

Proactivity refers to the tendency of an individual to take an active role in promoting others and/or the environment (Bateman \& Crant, 1993; Grant \& Ashford, 2008). For example, employees spontaneously solve problems, proactively propose ideas to improve the status quo of the organization, proactively seek information about work and the organization, proactively solicit feedback on work and performance, proactively engage in social activities, proactively propose innovative ideas, etc. (Grant \& Ashford, 2008; Parker, Williams, \& Turner, 2006; 
Morrison, 1993a, 1993b; Ashford, 1986; Ashford \& Black, 1996; Van Dyne \& LePine, 1998). Proactivity is not only conducive to the personal development of employees, such as improving employee performance, promoting career success, obtaining clear role positioning, better job satisfaction, and enhancing employee creativity (Parker \& Collins, 2010; Saks, Gruman, \& Cooper-Thomas, 2011; Kim, Hon, \& Crant, 2009; Kim, Hon, \& Lee, 2010) and also key factors that determine the success of an organization and its competitive advantage (Crant, 2000; Griffin, Neal, \& Parker, 2007, Frese, Kring, Soose, \& Zempel, 1996; Parker, 2000). Therefore, it has been paid more and more attention by researchers and managers.

Since Crant published a literature review on active behavior in 2000 (Crant, 2000), the proactivity of employees has become a hot topic in the field of organizational behavior. From the domestic point of view, Liu Mi and Hu Qing and other domestic scholars combed the two key concepts of employee proactivity in 2007 and 2011 respectively, i.e. proactive personality and proactive behavior. These reviews are helpful for scholars to further understand the research status of employee initiative, find the shortcomings in the research, and continue to promote the theoretical development in this field (Liu, Long, \& $\mathrm{Zu}, 2007$; Hu, Wang, Zhang, Cheng, \& Sun, 2011; Mao \& Sun, 2013). Since then, domestic scholars have published dozens of papers based on different theoretical perspectives on employee proactivity research in well-known journals at home and abroad. However, the development of these researches based on different perspectives and the lack of connection between them are not conducive to the comparison and integration of research results in this field. Therefore, it is necessary for us to further sort out, especially to discuss the theoretical perspectives of existing researches and the shortcomings of the current theoretical basis, which will help scholars to systematically understand the theoretical research in this field so as to adjust the research direction and focus in the future.

So, what are the new developments of these researches in the related construction and measurement in recent years? What are the main theoretical perspectives to solve the new problems? What other important issues have not been fully explored? What are the new trends of future research? In order to answer these key questions, so as to help researchers promote the further development of employee initiative research, we try to systematically comb the current research results of employee initiative from three aspects: construction, measurement and research methods, research perspective and related theories, and point out the future development direction for researchers on this basis.

\section{The Development of Construct, Measurement and Research Methods}

\subsection{The Development of Research Constructs}

The characteristics and behaviors of proactivity reflect the complementary tendencies and actions taken by individuals to shape themselves and their environment (for example, Bateman \& Crant, 1993; Grant \& Ashford, 2008). Research- 
ers mainly focus on proactive personality and proactive behavior. Proactivity personality refers to a stable behavioral tendency that individuals actively influence the surrounding environment (Bateman \& Crant, 1993). Individuals with proactive personality spontaneously create favorable environmental conditions to improve work performance rather than passively respond to the environment (Seibert, Crant, \& Kraimer, 1999). For a long time, scholars believe that proactive personality is a stable personality, which is not easily changed by the environment (Fugate, Prussia, \& Kinicki, 2012; Luthans, Avolio, Walumbwa, \& Li, 2005). However, some scholars have realized that personality has plasticity (Baltes, 1997; Caspi, Roberts, \& Shiner, 2005; Scollon \& Diener, 2006).

Proactive behavior refers to employees' initiative to improve the current environment or create a new environment, actively challenge the current situation, rather than passively adapt to the current environment (Crant, 2000). The specific proactive behavior in work is that employees actively ask for feedback on work and performance, take the initiative to help others, and actively innovate (Ashford, 1986; Spitzmuller \& Van Dyne, 2013; Vashdi, Bamberger, \& Erez, 2013; Parker et al., 2006). However, in different cultural background, the specific performance of employees' proactive behavior is different. For example, employees in a high power distance culture are more sensitive to authority, and they are more likely to be influenced by authority (for example, excluded by leaders and colleagues) than people in an individualistic culture. In this cultural context, employees' proactive behaviors are limited, and even do not involve the challenge status quo in the above definition (Gong, Cheung, Wang, \& Huang, 2012). In addition, employees in different career may be more inclined to different proactive behaviors due to individual differences in life cycle (Kanfer \& Ackerman, 2004). For example, the initiative of junior employees is more inclined to optimize performance, while senior employees are more concerned about how to minimize the loss (Freund, 2006). Therefore, some scholars suggest that we should grasp its essential characteristics in the research, instead of focusing on various specific manifestations (Grant \& Ashford, 2008). In addition, most scholars study the initiative behavior from the individual level. However, since 1999, some scholars have been exploring the initiative behavior at the team level (Kirkman \& Rosen, 1999; Tesluk \& Mathieu, 1999). Some scholars define team level proactivity as actions initiated by the team and focused on the future to change the external environment or internal state of the team (Erkutlu \& Chafra, 2012). The team's initiative behavior includes: the team actively introduces new working methods, actively prevents problems, not only passively responds to existing problems (Williams, Parker, \& Turner, 2010). Some individual proactive behaviors (such as employee voice behavior) can also occur at the team level (Li, Liao, Tangirala, \& Firth, 2017). However, because the main body of team initiative behavior is team or organization, it is difficult to implement such behavior by virtue of personal strength, so most of team proactive behavior cannot be completed at the individual level. 


\subsection{Development of Measurement and Research Methods}

In recent years, most scholars use questionnaire survey to measure the proactivity of employees, and most of them use self-report to collect data.

In terms of measurement tools, researchers mainly measure the degree of employees' proactivity from two aspects of personal characteristics and behavior process, that is, measuring the degree of employees' proactive personality and measuring the frequency of proactive behavior to collect data. In terms of personal characteristics, Bateman and Crant (1993) developed a one-dimensional initiative personality scale with 17 items, such as "I'm always looking for better working methods". Later scholars mostly used various simple versions of the scale. For example, Seibert et al. (1999) simplified the original scale with ten items in 1999. For example, "if I believe something, I will overcome difficulties and obstacles to achieve it". Other scholars adopted the simplified version of six items in 2005 by Claes et al. (2005), the sample items include: "this employee is always looking for a better way to complete the work", etc. These scales all reflect the degree of employees' initiative by asking the subjects' preference degree in the initiative events.

In the aspect of behavior process, scholars mostly use the proactive behavior scale developed by Griffin et al. (2007). The scale includes 9 items at three levels: individual, department and organization (Strauss, Parker, \& O’Shea, 2017; Yang et al., 2016). Examples of individual level initiatives such as "using better methods to complete core tasks"; examples of department level initiatives such as "developing new methods or improving original methods to help your team to complete tasks efficiently"; examples of department level initiatives such as "proposing to make internal work of the organization more efficient" The way of completion, etc. Some scholars selected eight items of specific proactive behaviors such as information seeking, such as "how often do you communicate with colleagues and supervisors on work-related topics in a week" (Major, Turner, \& Fletcher, 2006; Saks et al., 2011); three items of problem prevention, such as "subordinates' thoughts" Test the frequency of how to prevent the same problem from happening again; take charge of the three item scale of behavior, such as "subordinates try to propose solutions to urgent problems in the organization". In general, these scales show the degree of employees' initiative by measuring the frequency of the proactivity.

Whether it is measured from the perspective of personal characteristics or behavior process, it is focused on the proactivity of employees. In recent years, with the rise of team proactivity research, some scholars began to directly measure team level proactivity ( $\mathrm{Wu} \& \mathrm{Wang}, 2015)$. Using the team level proactivity scale developed by Baer and Frese (2003), the team leaders evaluate the whole team and directly obtain data on team proactivity. However, most team level data are still aggregated from individual proactivity to team level, not really measured from team level. Team proactive behavior is a kind of collective behavior tendency, in other words, it is about the behavior of the team as a collective, ra- 
ther than the sum of individual proactivity in the team (Morgeson \& Hofmann, 1999). Accordingly, the aggregation of team proactive behavior and team member proactive behavior is essentially different in measurement. From this point of view, if scholars study the initiative behavior at the team level, they should directly focus on the team or organization, rather than simply summing up individual proactivity data to represent the proactivity of the whole team.

From the perspective of measurement methods, due to the subjective bias of the general self-report questionnaire survey, the objectivity and inaccuracy of his assessment of the questionnaire survey, and the inability of the questionnaire survey method and the horizontal test itself to draw the conclusion of the cause and effect direction, many scholars have proposed that the future research can collect data from multiple sources at the same time (for example, using the supervisor self-report questionnaire survey method at the same time) I report, colleagues report and file investigation) to avoid the deviation caused by the independent use of self-evaluation or other evaluation, so as to ensure the accuracy and objectivity of the data (Ouyang et al., 2015), and optimize the design with the vertical experimental research of field experiment and laboratory experiment that can draw the causal inference (Sun \& Van Emmerik, 2015; Wu \& Parker, 2017).

\section{Research on Active Behavior Based on Different Theoretical Perspectives}

Previous studies have focused on the generation and mechanism of proactive behavior from the perspectives of personal characteristics and behavior process. From the perspective of personal characteristics, it is believed that there are differences in the individual's personal propensity to discover opportunities and examine problems, which is called proactive personality, that is, personality characteristics that are not limited by the environment and tend to change the environment (Bateman \& Crant, 1993). If employees have a high degree of proactive personality, they prefer to actively create a better environment for work, actively find and solve problems rather than passively respond. From the perspective of behavioral process, it is believed that the initiative mainly comes from the expectation of improving the status quo, that is, subordinates hope to bring greater benefits or avoid problems by improving the status quo, and these improvements can only be realized by their own active thinking and positive change to a large extent (Grant \& Ashford, 2008).

\subsection{Research from the Perspective of Personal Characteristics (Proactive Personality)}

\subsubsection{The Job Demands-Resources Model}

Previous studies have shown that employees are more likely to engage in work in a challenging and resource rich work environment and show the best performance (Demerouti \& Cropanzano, 2010). Therefore, the organization or management should provide employees with sufficient working resources, including 
feedback and social support (Nielsen, Randall, Yarker, \& Brenner, 2008; Piccolo \& Colquitt, 2006). However, organizations or managers are not always able to give feedback and support to employees in a timely manner. In this case, it is particularly important for employees to take the proactivity to optimize their work environment. The work demand resource model can explain the influence of employees' proactive personality on work results in this situation.

According to the theory of work demand resource model, when employees leave the organization, on the one hand, it is due to the mismatch between their ability and demand, on the other hand, it is due to the mismatch between the demand and supply of the organization (Edwards, 2008). People are not "passive recipients of environmental stress" (Buss, 1987), on the contrary, they may actively change their environment.

Employees who actively change their work environment can actively match their work resources with their abilities and needs (Tims \& Bakker, 2010). Therefore, from this model, some scholars think that employees with initiative personality are most likely to reshape their work (such as increasing social work resources and increasing their work challenges), actively adjust the work environment to maintain work enthusiasm, and then obtain positive in role performance evaluation (Bakker, Tims, \& Derks, 2012).

Previous studies have shown that employees with a proactive personality are good at discovering opportunities and taking action (Crant, 1995). Compared with previous studies, the theoretical perspective further shows that people with active personality are more inclined to change their working environment in a positive and active way by mobilizing working resources and demands. In addition, the theoretical perspective explains why and how employees proactively optimize their working environment when the general situation that organizations or leaders can't support employees in time occurs. According to this theoretical principle, the results of this perspective suggest that human resource managers should regularly carry out employee surveys, provide personalized feedback according to employees' views on current work needs and resources, and then improve the working environment in a targeted way so that they can work more efficiently with the support of the organization (Bakker et al., 2012).

\subsubsection{The Interactionist Model}

Previous studies focused on the positive environmental change of proactive personality in the workplace. However, this is only one aspect of the reciprocal relationship between proactive personality and environment. Many scholars believe that individual personality is "stable" (for example, Fugate et al., 2012), "not easy to develop and change" (for example, Luthans et al., 2005). However, personality psychologists increasingly recognize that personality is malleable over time (Baltes, 1997; Caspi et al., 2005; Scollon \& Diener, 2006). Exploring the influence mechanism of environment on proactive personality is helpful to further understand how to improve environmental factors to shape or attract more employees with proactive personality. Therefore, it is necessary to study the influence of 
work environment on proactive personality. The interaction model theory can respond to this research problem.

Interaction model theory emphasizes the interaction between human and environment. Although this theoretical perspective regards personality as a relatively permanent and stable behavior, thought or emotion pattern (Johnson, 1997), it also believes that personality characteristics are easily influenced by life and work experience in the whole life cycle (Baltes, 1997). Specifically, the theory assumes that over time, when individuals with certain personality characteristics choose a specific work environment, they gain the opportunity to express and further develop related skills and motivation, which in turn further strengthen their personality characteristics (Ackerman \& Heggestad, 1997; Roberts, Caspi, \& Moffitt, 2003). Although this theory has been a relatively mature system theory in personality psychology (Scollon \& Diener, 2006; Sutin \& Costa Jr., 2010), it has only recently begun to appear in the study of organizational behavior (such as Wu \& Griffin, 2012), especially suitable for the study of the reciprocal relationship between proactive personality and work attributes.

According to the interactionist model theory, people will be affected by their surroundings as well as their surroundings (Bandura, 1978, 2001). People with proactive personality are good at controlling their environment. They take the initiative to look for opportunities and take actions to achieve satisfactory changes (Bateman \& Crant, 1993). This change-oriented behavior tendency may increase their work autonomy, that is, the freedom of employees to make decisions at work (Hackman \& Oldham, 1975). People with active personality constantly change their environment. Whether these changes are successful or not, with the passage of time, repeated proactive behaviors are often consolidated, generalized and habitual, thus enhancing their active tendency (Caspi et al., 2005; Kohn \& Schooler, 1973). Therefore, according to the interaction theoretical model, some scholars propose that there is a dynamic relationship between active personality and work autonomy in the workplace, that is, active personality can improve the work autonomy of employees, and the improved work autonomy can further enhance the proactive personality of employees ( $\mathrm{Li}$, Fay, Frese, Harms, \& Gao, 2014).

It is necessary to explore the plasticity of proactive personality, because personality characteristics can affect people's work behavior. However, in the past, most studies considered that personality is a stable tendency. The plasticity of personality means that there is a way to influence the development of personality through intervention, so as to achieve the purpose of shaping ideal work behavior. By studying the dynamic reciprocal relationship between the specific variables of workplace environment and proactive personality, this theoretical perspective can help the scholars in the field of organizational behavior to further understand the dynamic change process of proactive personality, and further bring more enlightenment on how to improve the environmental factors of workplace to attract employees with proactive personality. 


\subsection{Research from the Perspective of Behavior Process (Proactive Behavior)}

\subsubsection{Social Identity Theory}

Scholars generally believe that the proactivity of employees is largely affected by the behavior of their superiors, especially the psychological process of subordinates after being abused by their superiors, so as to affect their proactive behavior? How to explain these psychological mechanisms reasonably is an important issue in this field (Belschak, Den Hartog, \& Fay, 2010). The theory of social identity helps to explain this kind of research problem.

Social identity theory (Tajfel \& Turner, 1986) holds that in order to define self-identity, people always classify themselves into specific groups similar to their beliefs and values, because groups are the source of self-identity information. People will compare their own group (inner group) with other groups (outer group). In the process of social comparison, they will form a sense of social identity for their group, and take positive actions to protect the interests of their group. Among all the members of the group, leaders are more typical individuals who can reflect the group norms, while other members will pay more attention to such people and be affected by them.

Proactive behavior requires a high degree of motivation (Parker, Bindl, \& Strauss, 2010), and employees' perceived internal identity may be the key motivation for workplace initiative. When leaders interact with subordinates in a way of support and respect, subordinates are likely to gain a high degree of internal status perception, while subordinates with a high degree of internal status perception define themselves as members of the organization, identify with their values and goals, and act in the way they expect. On the contrary, if they have a low sense of their internal status or even think that they are outsiders in the organization, they may not work actively (Armstrong-Stassen \& Schlosser, 2011). Therefore, some scholars use the theory of social identity for reference to explore the relationship between subordinates' perceived internal identity and negative leadership style and their active behaviors (Ouyang et al., 2015). The research finds that negative leadership style (such as abusive Leadership) can reduce subordinates' internal identity perception, thus reducing their active behaviors.

Social identity theory enriches the psychological process of active behavior operation by capturing subordinates' identity to the organization (i.e. perceived insider status). At the same time, the theoretical perspective also explores the role of the dark side of leadership behavior in active behavior, enriching the understanding of the role of the bright side of leadership behavior in active behavior in previous studies (Parker et al., 2010; Strauss, Griffin, \& Rafferty, 2009). From a practical point of view, the results of this study suggest that organizations should establish high-quality employee organizational relationships through promotion, training and other measures, improve employees' perception of the internal personnel of the organization, so as to avoid the adverse impact of abusive leadership, and strengthen employees' work initiative (Ouyang et al., 2015). 


\subsubsection{Theory of Planned Behavior}

Although previous studies have explored two antecedents of proactive behavior: individual differences (e.g., self-efficacy) and environmental factors (e.g., trust, management support) (Crant, 2000; Parker et al., 2006), we know how these antecedents affect proactive behavior and how to explain the relationship between them Very few. Active behavior is not a random decision, but a result of a rational decision due to certain risks. Therefore, it is necessary to clarify the cognitive mechanism of making such behavior decisions (Shin \& Kim, 2015). The theory of planned behavior can reveal the cognitive process of the relationship between specific antecedents and active behavior (Ajzen, 1991).

According to the theory of planned behavior, the intention (motivation) of an individual to a specific behavior directly determines whether or not the behavior is implemented, and the intention of an individual is influenced by the attitude, subjective norms and perceived behavior control of the individual to the behavior (Ajzen, 1991). Specifically, the more positive the attitude, the stronger the subjective norms, and the stronger the perceptual behavior control, the greater the behavioral intention, and vice versa (Duan \& Jiang, 2008).

Proactive behavior is a highly voluntary and rational behavior, which often involves changing the status quo or challenging the status quo, and has certain risks for employees. When the risk of responsibility is greater than the benefit, it means that the individual's attitude becomes negative, and the subjective norms and perceptual behavior control become weak, so the individual will reduce the willingness to take the initiative to avoid the risk (Morrison \& Phelps, 1999).

Therefore, the decision of employees' initiative behavior is likely to be affected by their intention to avoid risks. In order to explain how proactive behavior is driven by behavioral intention, some scholars based on the theoretical framework of planned behavior proposed that the stronger the perceived work support of employees, the stronger their subjective norms and behavioral intention, and thus more likely to produce proactive behavior; similarly, the higher the employee's work autonomy, the easier it is to control and conduct high individuals through perceived high behavior Active behavior for intention (Shin \& Kim, 2015).

This theory puts forward and tests the cognitive intermediary mechanism between antecedent variables and active behavior, explains the cognitive factors and mechanisms that affect active behavior, and shows that active behavior is a rational behavior involving individual will and rational decision-making, not only driven by individual personality (Crant, 2000). This breakthrough, which regards proactive behavior as rational behavior, further inspires future theoretical and empirical studies to pay attention to the complex decision-making process of proactive behavior. In addition, the findings from this theoretical perspective remind managers of organizations to help their employees develop proactive behavior by establishing perceptual norms and behavioral control (Shin \& Kim, 2015). 


\subsubsection{Attachment Theory}

Due to the potential uncertainty and high-risk consequences of proactive behavior, scholars initially believed that creating a supportive environment that encourages employees to make new attempts without worrying about potential obstacles can guarantee and promote employees' proactive behavior (Parker et al., 2010). Leaders play an important role in building such a supporting environment, for example, supporting and encouraging employees' efforts and giving them more authority (Avolio \& Bass, 1995). However, the following studies are controversial on whether leadership support can enhance employees' initiative behavior. Some scholars believe that there is a positive relationship between leadership support and various forms of active behavior (Axtell, Holman, Unsworth, \& Wall, 2000), but some people come to the opposite conclusion (Oldham \& Cummings, 1996; Parker et al., 2006). These inconsistent findings indicate that it is necessary to explore the important issue of whether and how leadership support affects employees' initiative behavior. In order to solve this problem, it needs to further explain which types of employees are more likely to benefit the most from leadership support. The attachment theory can provide a reasonable explanation for this problem.

According to attachment theory, individuals have the need to obtain a sense of security. In the early relationship with the main caregivers, adults with low attachment security tend to seek an effective alternative attachment character to obtain a sense of security (Bowlby, 1982).

In an organizational environment, leaders who provide secure support can be seen as effective substitutes for attachment figures (Mayseless \& Popper, 2007; Popper \& Mayseless, 2003). Therefore, based on attachment theory, some scholars believe that obtaining leadership safety support can positively predict employees' proactive behavior (Wu \& Parker, 2017).

This theoretical perspective, by distinguishing the types and boundary conditions of leader support, emphasizes the importance of interaction between situational factors (leader support) and temperament factors (attachment style) (Wu \& Parker, 2011), reveals the reasons why the previous research results on the influence of leader support on employees' proactive behavior are inconsistent, thus deepening our research on leaders How to create favorable working environment for employees' initiative behavior. From a practical point of view, this study suggests that organizations should train leaders to understand how to better support employees, encourage leaders to identify employees with different attachment styles, so that they can better create an organizational environment conducive to employee proactivity.

\subsubsection{Self Determination Theory}

In previous studies, scholars generally hold a positive and optimistic attitude towards proactive behavior, which is not conducive to our understanding of the possible negative effects of active behavior, nor to our understanding of the inconsistent results in the research. For example, there are inconsistent explana- 
tions on the impact of active behavior on employee happiness. On the one hand, some scholars believe that because proactive behavior needs higher level psychological functions, such as the expenditure of psychological resources such as planning, proactive behavior may consume people's resources and energy, leading to work pressure (Diamond, 2013; Van der Linden, Frese, \& Meijman, 2003; Belschak \& Den Hartog, 2010). On the other hand, other scholars believe that proactive behavior will not bring work pressure to employees (Strauss \& Parker, 2014). In order to solve this problem, some scholars respond to the above disputes from the perspective of self-determination theory.

According to self-determination theory, control motivation and autonomy motivation are two kinds of work motivation. Autonomous motivation refers to a kind of innate, internal and constructive consciousness tendency of self-improvement and integration. External motivation is called control motivation because it is driven by external factors and lacks of self-determination. Although controlling work motivation will lead to resource consumption, when the autonomous motivation is high, it will not consume resources or even generate action motivation due to the intrinsic recognition of individual value, thus compensating the resources consumed by controlling work motivation (Moller, Deci, \& Ryan, 2006).

Whether or not proactive behavior leads to experience exhaustion depends on the individual's work motivation. When the resource consumption is greater than the resource productivity, proactive behavior will lead to resource loss, which will lead to work pressure (Strauss et al., 2017). Specifically speaking, the controlled motivation in the work consumes the resources involved in the active behavior. The autonomous motivation can make the individual experience the self-recognition of their own behavior, not only will not lead to the lack of resources, but also enhance the sense of energy (Deci \& Ryan, 2008; Moller, Deci, \& Ryan, 2006). When the autonomous motivation in the work does not compensate the resources consumed by the control motivation, it will lead to the loss of resources, which will lead to work pressure, setbacks and failures. Therefore, based on the theory of self-determination, some scholars have proposed that when the control motivation is high and the autonomy motivation is low, the proactive behavior of employees will increase the work pressure of employees (Strauss et al., 2017).

In short, the theoretical perspective responds to the contradictory prediction of the impact of proactive behavior on employees' psychological stress. In view of the rising cost of psychological stress in the workplace, the theoretical explanation provided by this theoretical perspective is an important breakthrough, and it enlightens organizations to take corresponding measures to improve employees' autonomous motivation, and then to prevent the work pressure caused by the proactive behavior.

\section{Research Prospect}

Personal trait perspective: the interaction between human and environment is 
influenced by the trait difference, that is, the proactive personality. Different individuals show different behavioral tendencies. From the perspective of personal characteristics, the proactivity is a characteristic of employees themselves. Even if they are not forced by the environment, or there is no interest exchange and other situations, employees will make initiative behaviors based on their personal preferences. For example, based on the work demand resource model, employees with proactive personality can also actively change the work environment to get the conclusion that the work demand and resources match their own abilities. However, the theoretical perspective is based on the theory of human environment interaction, so individuals with proactive personality are only relatively not limited by the power of environment (Bateman \& Crant, 1993). For example, based on the interactive model theory, this paper explores the dynamic reciprocal relationship between active personality and work environment factors, and empirically tests the important concerns in the field of organizational behavior on the impact of work environment on proactive personality plasticity.

Behavior process perspective: active behavior describes a specific spontaneous action process (Crant, 2000). It is the externalization of individual proactivity. From this perspective, proactivity can be embodied in the actual behavior of individuals, and has a substantial impact on the environment. For example, based on the theory of social identity, this paper discusses the relationship between the perceived internal identity of subordinates, abusive leadership and their proactive behaviors, explains that even in the face of high risk, employees will show proactive behaviors out of the perception of their internal identity and the identification of the organization, enriching the psychological process of the operation of proactive behaviors, and proposes proactive behaviors based on the theory of planned behaviors. Based on attachment theory, this paper analyzes the regulatory role of employees with different attachment types in obtaining leadership's safety support and proactive behavior, and reconciles the inconsistent results of previous studies on the impact of leadership support on employees' proactive behavior, thus deepening our research on how leaders enhance employees' proactive behavior. Based on the theory of self-determination, this paper puts forward that whether the proactive behavior will lead to the exhaustion of resources depends on the individual's work motivation, and responds to the contradictory explanation about the influence of the initiative behavior on the individual's psychological well-being.

\section{Future Outlook}

Although the research from the perspective of personal characteristics and behavior process enriches our understanding of the formation and mechanism of employee proactivity, however, from the above review, we can find that the current development trend and research deficiencies in this field, so as to further promote the research and development in the following aspects. 


\subsection{New Theoretical Explanation}

Both personal characteristics and behavioral process perspectives ignore an important consequence of proactive behavior. Employees' proactive behavior means that they need to challenge the status quo and take some risk of failure (Grant, Parker, \& Collins, 2009). In this case, why are proactive employees willing to take this potential risk and actively change the status quo? Therefore, the current research on the mechanism of active behavior is not comprehensive.

The theory of "benefit seeking and harm avoiding framework" can further explain this problem. In the process of active behavior, employees with a high degree of active personality mainly focus on two aspects: Mining opportunities and avoiding problems. These two aspects are included in the basic human psychology and behavior patterns discussed in the theory of "benefit seeking and harm avoiding framework". According to the theory of "benefit seeking and harm avoiding framework", whether it is individual personality, motivation, emotion, cognitive tendency, or ultimately behavior, two different mechanisms of benefit seeking and harm avoiding can be included according to their responses to positive and negative stressors (such as events or information) (Elliot \& Thrash, 2002). Because opportunities and problems represent positive and negative stressors respectively, it means that proactive behavior can also be studied with the theory of "benefit seeking and harm avoiding framework". In addition, the behavioral process discussed in the theory of "benefit seeking and harm avoiding framework" emphasizes that since the stress comes from the interaction between people, the mechanism of "benefit seeking and harm avoiding" needs to be studied in the interactive context, which means that the theory is applicable to the research in the team work context where interaction is needed (Ferris, Yan, Lim, Chen, \& Fatimah, 2016). Therefore, with the help of this theory, we can deeply analyze the essence and connotation of proactive personality and behavior, and explore the mechanism of proactive behavior, so as to construct and test a new theoretical framework, so as to better grasp the initiative behavior of employees in team work as a whole, which may provide new management ideas for promoting the proactive behavior practice of employees.

\subsection{New Development Trend}

Although there are many literatures about active behavior, most of them are isolated from each other. Therefore, some scholars suggest that we should study the similarity between proactive behaviors (Grant \& Ashford, 2008). We found that different active behaviors have both the active approach to positive stimulation and the active avoidance of negative stimulation. But both of them emphasize the nature of proactive tendency. For example, the behavior of making suggestions is an out of role behavior in which members of an organization offer their opinions to the organization (Van Dyne \& LePine, 1998). Liang et al. (2012) further put forward a two-dimensional model of suggestion behavior, in which the promotion suggestion mainly emphasizes the behavior of putting forward 
constructive opinions in order to promote the development of the organization, tends to enhance the positive impact on the organization, while the inhibition suggestion emphasizes the behavior of putting forward preventive suggestions for the problems adverse to the development of the organization, tends to reduce the negative impact in the organization Ring. These concrete research on the suggestion behavior can be incorporated into the research logic of " proactive behavior", which is helpful to integrate and expand from the theoretical framework of the system.

In addition, the perspective of personality characteristics and the perspective of behavior process need to be further integrated. Some scholars believe that proactive personality is an important antecedent variable of proactive behavior, which can lead to active behavior (Frese, 1997). Approaching or staying away from stimuli (i.e., seeking benefits or avoiding harm) is the most basic and widely used mode of differentiation in human life (Elliot, 2006). In addition, in terms of biology, human beings have two independent qualities of seeking advantages and avoiding disadvantages, whose effects are manifested in personality traits, motivation system and behavior results (Elliot \& Thrash, 2002). Therefore, the distinction model of benefit seeking and harm avoiding (or individual sensitivity to positive and negative stimuli) can be used as a general principle to guide individual differences (personality), motivational constructs and the relationship between various behavioral outcomes (Elliot \& Church, 1997; Elliot \& Thrash, 2002). Furthermore, according to Elliot's framework hierarchy model, individuals with different personalities cause corresponding behavioral motivation according to their sensitivity to positive and negative stressors, and produce corresponding behavioral results through guidance of specific behavioral goals (Elliot \& Thrash, 2002). That is to say, individuals with positive personalities are more sensitive to positive information and are more likely to produce positive convergence, the motivation of the results, and then produce the corresponding behavior of interest. The individual of avoiding harm personality is more sensitive to negative information, more likely to produce the motivation of avoiding negative results, and then produce the corresponding behavior of avoiding harm.

In view of the basic and extensive application of the pattern differentiation in life, it can be assumed that: the mechanism of employees' proactive behavior and active behavior of avoiding harm may also be in line with the above pattern, that is, employees with profit-seeking initiative personality are more likely to generate profit-seeking initiative behavior by approaching success motivation; employees with harm avoiding proactive personality are more likely to generate profit-seeking proactive behavior by approaching success motivation It is possible that avoiding failure motivation can lead to avoiding harm proactive behavior.

\subsection{New Analysis Level}

From a practical point of view, proactive behavior occurs more in the team work of enterprises. Since the organization itself is composed of various formal teams 
and informal groups, most of the employees' behaviors or work are carried out in the team environment (Moreland, Levine, \& McMinn, 2001). Therefore, compared with the study of the proactive behavior as a phenomenon of individual employees in the whole organization, the further focus on the team can better meet the needs of management practice. However, the current relevant research does not further refine the proactive behavior to the team level, so there is a lack of sufficient understanding of the proactive behavior of employees in the team. When enterprises apply these research results, the practical effect may be reduced. Therefore, the future research results on team level proactive behavior can provide managers with effective management intervention from the team level, so as to better enhance the proactive behavior of employees.

\section{Conflicts of Interest}

The author declares no conflicts of interest regarding the publication of this paper.

\section{References}

Ackerman, P. L., \& Heggestad, E. D. (1997). Intelligence, Personality, and Interests: Evidence for Overlapping Traits. Psychological Bulletin, 121, 219-245.

https://doi.org/10.1037/0033-2909.121.2.219

Ajzen, I. (1991). The Theory of Planned Behavior. Organizational Behavior and Human Decision Processes, 50, 179-211. https://doi.org/10.1016/0749-5978(91)90020-T

Armstrong-Stassen, M., \& Schlosser, F. (2011). Perceived Organizational Membership and the Retention of Older Workers. Journal of Organizational Behavior, 32, 319-344. https://doi.org/10.1002/job.647

Ashford, S. J. (1986). Feedback Seeking in Individual Adaptation: A Resource Perspective. Academy of Management Journal, 29, 465-487. https://doi.org/10.5465/256219

Ashford, S. J., \& Black, J. S. (1996). Proactivity during Organizational Entry: The Role of Desire for Control. Journal of Applied Psychology, 81, 199-214. https://doi.org/10.1037/0021-9010.81.2.199

Avolio, B. J., \& Bass, B. M. (1995). Individual Consideration Viewed at Multiple Levels of Analysis: A Multi-Level Framework for Examining the Diffusion of Transformational Leadership. The Leadership Quarterly, 6, 199-218. https://doi.org/10.1016/1048-9843(95)90035-7

Axtell, C. M., Holman, D. J., Unsworth, K. L., \& Wall, T. D. (2000). Shopfloor Innovation: Facilitating the Suggestion and Implementation of Ideas. Journal of Occupational and Organizational Psychology, 73, 265-285. https://doi.org/10.1348/096317900167029

Baer, M., \& Frese, M. (2003). Innovation Is Not Enough: Climates for Initiative and Psychological Safety, Process Innovations, and Firm Performance. Journal of Organizational Behavior, 24, 45-68. https://doi.org/10.1002/job.179

Bakker, A. B., Tims, M., \& Derks, D. (2012). Proactive Personality and Job Performance: The Role of Job Crafting and Work Engagement. Human Relations, 65, 1359-1378. https://doi.org/10.1177/0018726712453471

Baltes, P. B. (1997). On the Incomplete Architecture of Human Ontogeny: Selection, Optimization, and Compensation as Foundation of Developmental Theory. American Psychologist, 52, 366-380. https://doi.org/10.1037/0003-066X.52.4.366

Bandura, A. (1978). The Self System in Reciprocal Determinism. American Psychologist, 
33, 344-358. https://doi.org/10.1037/0003-066X.33.4.344

Bandura, A. (2001). Social Cognitive Theory: An Agentic Perspective. Annual Review of Psychology, 52, 1-26. https://doi.org/10.1146/annurev.psych.52.1.1

Bateman, T. S., \& Crant, J. M. (1993). The Proactive Component of Organizational Behavior: A Measure and Correlates. Journal of Organizational Behavior, 14, 103-118. https://doi.org/10.1002/job.4030140202

Belschak, F D., \& Den Hartog, D. N. (2010). Being Proactive at Work-Blessing or Bane? The Psychologist, 23, 2-5.

Belschak, F. D., Den Hartog, D. N., \& Fay, D. (2010). Exploring Positive, Negative and Context-Dependent Aspects of Proactive Behaviours at Work. Journal of Occupational and Organizational Psychology, 83, 267-273. https://doi.org/10.1348/096317910X501143

Bowlby, J. (1982). Attachment and Loss: Retrospect and Prospect. The American Journal of Orthopsychiatry, 52, 664-678. https://doi.org/10.1111/j.1939-0025.1982.tb01456.x

Buss, D. M. (1987). Selection, Evocation, and Manipulation. Journal of Personality and Social Psychology, 53, 1214-1221. https://doi.org/10.1037/0022-3514.53.6.1214

Caspi, A., Roberts, B. W., \& Shiner, R. L. (2005). Personality Development: Stability and Change. Annual Review of Psychology, 56, 453-484.

https://doi.org/10.1146/annurev.psych.55.090902.141913

Claes, R., Beheydt, C., \& Lemmens, B. (2005). Unidimensionality of Abbreviated Proactive Personality Scales across Cultures. Applied Psychology, 54, 476-489. https://doi.org/10.1111/j.1464-0597.2005.00221.x

Crant, J. M. (2000). Proactive Behavior in Organizations. Journal of Management, 26, 435-462. https://doi.org/10.1177/014920630002600304

Deci, E. L., \& Ryan, R. M. (2008). Self-Determination Theory: A Macrotheory of Human Motivation, Development, and Health. Canadian Psychology/Psychologie Canadienne, 49,, 182-185. https://doi.org/10.1037/a0012801

Demerouti, E., \& Cropanzano, R. (2010). From Thought to Action: Employee Work Engagement and Job Performance. In A. B. Bakker, \& M. P. Leiter (Eds.), Work Engagement: A Handbook of Essential Theory and Research (pp. 147-163). New York: Psychology Press.

Diamond, A. (2013). Executive Functions. Annual Review of Psychology, 64, 135-168. https://doi.org/10.1146/annurev-psych-113011-143750

Duan, W. T., \& Jiang, G. R. (2008). A Review of the Theory of Planned Behavior. Advances in Psychological Science, 16,315-320.

Edwards, J. R. (2008). Person-Environment Fit in Organizations: An Assessment of Theoretical Progress. The Academy of Management Annals, 2, 167-230. https://doi.org/10.5465/19416520802211503

Elliot, A. J. (2006). The Hierarchical Model of Approach-Avoidance Motivation. Motivation and Emotion, 30, 111-116. https://doi.org/10.1007/s11031-006-9028-7

Elliot, A. J., \& Church, M. A. (1997). A Hierarchical Model of Approach and Avoidance Achievement Motivation. Journal of Personality and Social Psychology, 72, 218-232. https://doi.org/10.1037/0022-3514.72.1.218

Elliot, A. J., \& Thrash, T. M. (2002). Approach-Avoidance Motivation in Personality: Approach and Avoidance Temperaments and Goals. Journal of Personality and Social Psychology, 82, 804-818. https://doi.org/10.1037/0022-3514.82.5.804

Erkutlu, H., \& Chafra, J. (2012). The Impact of Team Empowerment on Proactivity: The 
Moderating Roles of Leader's Emotional Intelligence and Proactive Personality. Journal of Health Organization and Management, 26, 560-577. https://doi.org/10.1108/14777261211256918

Ferris, D. L., Yan, M., Lim, V. K., Chen, Y., \& Fatimah, S. (2016). An Approach-Avoidance Framework of Workplace Aggression. Academy of Management Journal, 59, 1777-1800. https://doi.org/10.5465/amj.2014.0221

Frese, M., Kring, W., Soose, A., \& Zempel, J. (1996). Personal Initiative at Work: Differences between EAST and West Germany. Academy of Management Journal, 39, 37-63. https://doi.org/10.2307/256630

Freund, A. M. (2006). Age-Differential Motivational Consequences of Optimization Versus Compensation Focus in Younger and Older Adults. Psychology and Aging, 21, 240-252. https://doi.org/10.1037/0882-7974.21.2.240

Fugate, M., Prussia, G E., \& Kinicki, A. J. (2012). Managing Employee Withdrawal during Organizational Change: The Role of Threat Appraisal. Journal of Management, 38, 890-914. https://doi.org/10.1177/0149206309352881

Gong, Y., Cheung, S. Y., Wang, M., \& Huang, J. C. (2012). Unfolding the Proactive Process for Creativity: Integration of the Employee Proactivity, Information Exchange, and Psychological Safety Perspectives. Journal of Management, 38, 1611-1633. https://doi.org/10.1177/0149206310380250

Grant, A. M., \& Ashford, S. J. (2008). The Dynamics of Proactivity at Work. Research in Organizational Behavior, 28, 3-34. https://doi.org/10.1016/j.riob.2008.04.002

Grant, A. M., Parker, S., \& Collins, C. (2009). Getting Credit for Proactive Behavior: Supervisor Reactions Depend on What You Value and How You Feel. Personnel Psychology, 62, 31-55. https://doi.org/10.1111/j.1744-6570.2008.01128.x

Griffin, M. A., Neal, A., \& Parker, S. K. (2007). A New Model of Work Role Performance: Positive Behavior in Uncertain and Interdependent Contexts. Academy of Management Journal, 50, 327-347. https://doi.org/10.5465/amj.2007.24634438

Hackman, J. R., \& Oldham, G. R. (1975). Development of the Job Diagnostic Survey. Journal of Applied Psychology, 60, 159-170. https://doi.org/10.1037/h0076546

Hu, Q., Wang, S. N., Zhang, X. W., Cheng, B., \& Sun, H. W. (2011). Review and Prospect of Active Behavior in Work. Advances in Psychological Science, 19, 1534-1543.

Johnson, J. A. (1997). Units of Analysis for the Description and Explanation of Personality. In R. Hogan, J. A. Johnson, \& S. R. Briggs (Eds.), Handbook of Personality Psychology (pp. 73-93). San Diego, CA: Academic Press. https://doi.org/10.1016/B978-012134645-4/50004-4

Kanfer, R., \& Ackerman, P. L. (2004). Aging, Adult Development, and Work Motivation. Academy of Management Review, 29, 440-458. https://doi.org/10.5465/amr.2004.13670969

Kim, T. Y., Hon, A. H., \& Crant, J. M. (2009). Proactive Personality, Employee Creativity, and Newcomer Outcomes: A Longitudinal Study. Journal of Business and Psychology, 24, 93-103. https://doi.org/10.1007/s10869-009-9094-4

Kim, T., Hon, A. H., \& Lee, D. (2010). Proactive Personality and Employee Creativity: The Effects of Job Creativity Requirement and Supervisor Support for Creativity. Creativity Research Journal, 22, 37-45. https://doi.org/10.1080/10400410903579536

Kirkman, B. L., \& Rosen, B. (1999). Beyond Self-Management: Antecedents and Consequences of Team Empowerment. Academy of Management Journal, 42, 58-74. https://doi.org/10.2307/256874

Kohn, M. L., \& Schooler, C. (1973). Occupational Experience and Psychological Func- 
tioning: An Assessment of Reciprocal Effects. American Sociological Review, 38, 97-118. https://doi.org/10.2307/2094334

Li, A. N., Liao, H., Tangirala, S., \& Firth, B. M. (2017). The Content of the Message Matters: The Differential Effects of Promotive and Prohibitive Team Voice on Team Productivity and Safety Performance Gains. Journal of Applied Psychology, 102, 1259-1270. https://doi.org/10.1037/apl0000215

Li, W. D., Fay, D., Frese, M., Harms, P. D., \& Gao, X. Y. (2014). Reciprocal Relationship between Proactive Personality and Work Characteristics: A Latent Change Score Approach. Journal of Applied Psychology, 99, 948-965. https://doi.org/10.1037/a0036169

Liang, J., Farh, C. I., \& Farh, J. L. (2012). Psychological Antecedents of Promotive and Prohibitive Voice: A Two-Wave Examination. Academy of Management Journal, 55, 71-92. https://doi.org/10.5465/amj.2010.0176

Liu, M., Long, L. R., \& Zu, W. (2007). Research Status and Prospects of Active Personality. Advances in Psychological Science, 15, 333-337.

Luthans, F., Avolio, B. J., Walumbwa, F. O., \& Li, W. (2005). The Psychological Capital of Chinese Workers: Exploring the Relationship with Performance. Management and Organization Review, 1, 249-271. https://doi.org/10.1111/j.1740-8784.2005.00011.x

Major, D. A., Turner, J. E., \& Fletcher, T. D. (2006). Linking Proactive Personality and the Big Five to Motivation to Learn and Development Activity. Journal of Applied Psychology, 91, 927-935. https://doi.org/10.1037/0021-9010.91.4.927

Major, Turner, H., \& Fletcher (1986). The Social Identity Theory of Intergroup Behavior. In S. Worchel, \& W. G. Austin (Eds.), Psychology of Intergroup Relations (2nd ed., pp. 7-24). Chicago, IL: Nelson-Hall.

Mao, C. G., \& Sun, J. M. (2013). Research on Harm of Uncivilized Behavior in Workplace Based on Active Personality Regulation. Chinese Journal of Management, 10, 708-714.

Mayseless, O., \& Popper, M. (2007). Reliance ON Leaders and Social Institutions: An Attachment Perspective. Attachment \& Human Development, 9, 73-93.

https://doi.org/10.1080/14616730601151466

Moller, A. C., Deci, E. L., \& Ryan, R. M. (2006). Choice and Ego-Depletion: The Moderating Role of Autonomy. Personality and Social Psychology Bulletin, 32, 1024-1036. https://doi.org/10.1177/0146167206288008

Moreland, R. L., Levine, J. M., \& McMinn, J. G. (2001). Self-Categorization and Workgroup Socialization. In M. A. Hogg, \& D. Terry (Eds.), Social Identity Processes in Organizational Contexts (pp. 87-100). Philadelphia: Psychology Press.

Morgeson, F. P., \& Hofmann, D. A. (1999). The Structure and Function of Collective Constructs: Implications for Multilevel Research and Theory Development. Academy of Management Review, 24, 249-265. https://doi.org/10.5465/amr.1999.1893935

Morrison, E. W. (1993a). Newcomer Information Seeking: Exploring Types, Modes, Sources, and Outcomes. Academy of Management Journal, 36, 557-589. https://doi.org/10.5465/256592

Morrison, E. W. (1993b). Longitudinal Study of the Effects of Information Seeking on Newcomer Socialization. Journal of Applied Psychology, 78, 173-183. https://doi.org/10.1037/0021-9010.78.2.173

Morrison, E. W., \& Phelps, C. C. (1999). The Taking Work at Charge: Extrarole Efforts to Initiate Workplace Change. Academy of Management Journal, 42, 403-419. https://doi.org/10.2307/257011

Nielsen, K., Randall, R., Yarker, J., \& Brenner, S. O. (2008). The Effects of Transformational Leadership on Followers' Perceived Work Characteristics and Psychological 
Well-Being: A Longitudinal Study. Work \& Stress, 22, 16-32. https://doi.org/10.1080/02678370801979430

Oldham, G. R., \& Cummings, A. (1996). Employee Creativity: Personal and Contextual Factors at Work. Academy of Management Journal, 39, 607-634. https://doi.org/10.5465/256657

Ouyang, K., Lam, W., \& Wang, W. (2015). Roles of Gender and Identification on Abusive Supervision and Proactive Behavior. Asia Pacific Journal of Management, 32, 671-691. https://doi.org/10.1007/s10490-015-9410-7

Parker, S. K. (2000). From Passive to Proactive Motivation: The Importance of Flexible Role Orientations and Role Breadth Self Efficacy. Applied Psychology: An International Review, 49, 447-469. https://doi.org/10.1111/1464-0597.00025

Parker, S. K., \& Collins, C. G. (2010). Taking Stock: Integrating and Differentiating Multiple Proactive Behaviors. Journal of Management, 36, 633-662. https://doi.org/10.1177/0149206308321554

Parker, S. K., Bindl, U. K., \& Strauss, K. (2010). Making Things Happen: A Model of Proactive Motivation. Journal of Management, 36, 827-856.

https://doi.org/10.1177/0149206310363732

Parker, S. K., Williams, H. M., \& Turner, N. (2006). Modeling the Antecedents of Proactive Behavior at Work. Journal of Applied Psychology, 91, 636-652. https://doi.org/10.1037/0021-9010.91.3.636

Piccolo, R. F., \& Colquitt, J. A. (2006). Transformational Leadership and Job Behaviors: The Mediating Role of Core Job Characteristics. Academy of Management Journal, 49, 327-340. https://doi.org/10.5465/amj.2006.20786079

Popper, M., \& Mayseless, O. (2003). Back to Basics: Applying a Parenting Perspective to Transformational Leadership. The Leadership Quarterly, 14, 41-65. https://doi.org/10.1016/S1048-9843(02)00183-2

Roberts, B. W., Caspi, A., \& Moffitt, T. E. (2003). Work Experiences and Personality Development in Young Adulthood. Journal of Personality and Social Psychology, 84, 582-593. https://doi.org/10.1037/0022-3514.84.3.582

Saks, A. M., Gruman, J. A., \& Cooper-Thomas, H. (2011). The Neglected Role of Proactive Behavior and Outcomes in Newcomer Socialization. Journal of Vocational Behavior, 79, 36-46. https://doi.org/10.1016/j.jvb.2010.12.007

Scollon, C. N., \& Diener, E. (2006). Love, Work, and Changes in Extraversion and Neuroticism over Time. Journal of Personality and Social Psychology, 91, 1152-1165. https://doi.org/10.1037/0022-3514.91.6.1152

Seibert, S. E., Crant, J. M., \& Kraimer, M. L. (1999). Proactive Personality and Career Success. Journal of Applied Psychology, 84, 416-427.

https://doi.org/10.1037/0021-9010.84.3.416

Shin, Y., \& Kim, M. J. (2015). Antecedents and Mediating Mechanisms of Proactive Behavior: Application of the Theory of Planned Behavior. Asia Pacific Journal of Management, 32, 289-310. https://doi.org/10.1007/s10490-014-9393-9

Spitzmuller, M., \& Van Dyne, L. (2013). Proactive and Reactive Helping: Contrasting the Positive Consequences of Different Forms of Helping. Journal of Organizational Behavior, 34, 560-580. https://doi.org/10.1002/job.1848

Strauss, K., \& Parker, S. K. (2014). Effective and Sustained Proactivity in the Workplace: A Self-Determination Theory Perspective. In M. Gagné (Ed.), The Oxford Handbook of Work Engagement, Motivation, and Self-Determination Theory (pp. 50-71). Oxford: Oxford University Press. 
Strauss, K., Griffin, M. A., \& Rafferty, A. E. (2009). Proactivity Directed toward the Team and Organization: The Role of Leadership, Commitment and Role-Breadth Self-Efficacy. British Journal of Management, 20, 279-291. https://doi.org/10.1111/j.1467-8551.2008.00590.x

Strauss, K., Parker, S. K., \& O'Shea, D. (2017). When Does Proactivity Have a Cost? Motivation at Work Moderates the Effects of Proactive Work Behavior on Employee Job Strain. Journal of Vocational Behavior, 100, 15-26.

https://doi.org/10.1016/j.jvb.2017.02.001

Sun, S., \& Van Emmerik, H. I. (2015). Are Proactive Personalities Always Beneficial? Political Skill as a Moderator. Journal of Applied Psychology, 100, 966-975. https://doi.org/10.1037/a0037833

Sutin, A. R., \& Costa Jr., P. T. (2010). Reciprocal Influences of Personality and Job Characteristics across Middle Adulthood. Journal of Personality, 78, 257-288. https://doi.org/10.1111/j.1467-6494.2009.00615.x

Tesluk, P. E., \& Mathieu, J. E. (1999). Overcoming Roadblocks to Effectiveness: Incorporating Management of Performance Barriers into Models of Work Group Effectiveness. Journal of Applied Psychology, 84, 200-217. https://doi.org/10.1037/0021-9010.84.2.200

Tims, M., \& Bakker, A. B. (2010). Job Crafting: Towards a New Model of Individual Job Redesign. SA Journal of Industrial Psychology, 36, 1-9. https://doi.org/10.4102/sajip.v36i2.841

Van der Linden, D., Frese, M., \& Meijman, T. F. (2003). Mental Fatigue and the Control of Cognitive Processes: Effects on Perseveration and Planning. Acta Psychologica, 113, 45-65. https://doi.org/10.1016/S0001-6918(02)00150-6

Van Dyne, L., \& LePine, J. (1998). Helping and Voice Extra-Role Behavior: Evidence of Construct and Predictive Validity. Academy of Management Journal, 47, 108-119. https://doi.org/10.2307/256902

Vashdi, D., Bamberger, P., \& Erez, M. (2013). Can Surgical Teams Ever Learn? Towards a Theory of Transitive Team Learning in Action Teams. Academy of Management Journal, 56, 945-971. https://doi.org/10.5465/amj.2010.0501

Williams, H. M., Parker, S. K., \& Turner, N. (2010). Proactively Performing Teams: The Role of Work Design, Transformational Leadership, and Team Composition. Journal of Occupational and Organizational Psychology, 83, 301-324. https://doi.org/10.1348/096317910X502494

Wu, C. H., \& Parker, S. K. (2011). Proactivity in the Work Place: Looking Back and Looking Forward. In K. Cameron, \& G. Spreitzer (Eds.), The Oxford Handbook of Positive Organizational Scholarship (pp. 84-96). New York: Oxford University Press.

Wu, C. H., \& Parker, S. K. (2017). The Role of Leader Support in Facilitating Proactive Work Behavior: A Perspective from Attachment Theory. LSE Research Online Documents on Economics, 43, 1025-1049. https://doi.org/10.1177/0149206314544745

Wu, C. H., \& Wang, Z. (2015). How Transformational Leadership Shapes Team Proactivity: The Mediating Role of Positive Affective Tone and the Moderating Role of Team Task Variety. Group Dynamics: Theory, Research, and Practice, 19, 137-151. https://doi.org/10.1037/gdn0000027

Yang, Z. F., Chen, Q.-W., Zhu, Y., \& Zeng, B. (2016). Is spiritual Leadership One of the Drivers of Proactive Behavior? Testing of a Multiple Mediating Effects Model. Management Review, 28, 191-202. 